\title{
Mengatasi Kenakalan Pada Siswa Melalui Pendekatan Konseling Behavioral
}

\author{
Sulthon \\ Institut Agama Islam Negeri (IAIN) Kudus \\ sulthon52@gmail.com
}

\begin{abstract}
Abstrak
Kenakalan anak merupakan wujud dari dinamika psikologis yang terjadi karena adanya tumbuh dan kembang yang dialami individu siswa yang mengarah pada terjadinya perilaku yang berbeda. Perilaku yang menyimpang yang dilakukan anak banyak disebabkan karena pengaruh dari luar atau teman sebaya. Perilaku siswa yang menyimpang atau mengalami kenakalan dapat diperbaiki dengan perilaku yang baik melalui pemberian stimulus yang baik dengan memperkuat perilaku adaptif dan memperlemah perilaku yang menyimpang dengan pengkondisian yang tetap. Konseling behavior merupakan upaya untuk mengatasi kenakalan siswa dengan menggunakan teknik desensitisasi sistemik, pelatihan asertif dan time out.
\end{abstract}

Kata kunci: Mengatasi, Kenakalan siswa, pendekatan konseling behavioral.

\begin{abstract}
Child delinquency is a manifestation of the psychological dynamics that occurs due to the growth experienced by individual students that leads to the occurrence of different behavior. Deviant behavior carried out by children is caused by the influences from the outside or peers. Student behavior that deviates or experienced delinquency can be fixed with good behavior through the granting of a good stimulus by strengthening the adaptive behavior and weaken deviant behavior with constant conditioning. Behavior counseling is an attempt to overcome the student's misbehavior with the use of systemic desensitization techniques, assertive training and time out.
\end{abstract}

Keywords: Overcoming, Students delinquency, Behavioral Counseling Approach. 


\section{A. Pendahuluan}

Anak adalah individu yang sedang tumbuh dan berkembang, dalam tumbuh dan kembang seorang individu akan mengalami dinamika psikologis. Perubahan dari waktu ke waktu akan selalu terjadi. Dari sinilah sering terjadi permasalahan antara anak dan orang tua. Sering terjadi perbedaan pandangan, sikap dan perilaku yang ditampilkan yang terkadang tidak sesuai dengan norma yang selama ini ditanamkan oleh orang tua atau guru.

Terjadinya perubahan perilaku pada anak sebenarnya merupakan keniscayaan pada diri individu. Disebut demikian karena secara psikologis, dengan bertambahnya kematangan biologis, akan bertambah pula berfungsinya kemampuan psikologis akibat kematangan yang terjadi. Seperti terjadinya kematangan indra maka akan menyebabkan seorang anak akan bertambah kepandaiannya untuk memfungsikan indera tersebut. Bertambahnya kemampuan yang terjadi pada anak ini, selanjutnya akan berpengaruh pada terjadinya perubahan perilakunya yang terkadang bagi orang tua atau guru disebut nakal manakala perilaku tersebut bertentangan dengan nilai yang ditanamkan.

Kata anak nakal sebenarnya pada awalnya muncul diartikan sebagai bertambahnya kepintaran pada anak. Dalam pengertian bahasa Jawa digunakan untuk menyebut "ana akal" artinya anak mulai bertambah akalnya atau anak mulai ada kemampuan untuk berpikir walaupun masih sebatas hitam putih. Seperti dalam ilustrasi ini, "ketika anak tertarik mainan yang bisa berjalan atau berbunyi maka anak akan mengamati dengan seksama dan memainkannya dengan rasa ingin tahunya kenapa ini bisa berbunyi lalu berusaha ingin membongkar bagian mana yang menyebabkan ini berbunyi, berarti anak yang demikian adalah tanda ana akalnya baik atau pandai".

Dari kenyataan inilah, maka dapat dijelaskan bahwa terjadinya perubahan kemampuan yang terjadi secara terus-menerus akan menyebabkan anak akan mengalami perubahan perilakunya. Sedang perubahan perilaku tersebut terkadang tidak sesuai dengan nilai-nilai yang dibiasakan orang tua karena mungkin dianggap menyimpang atau melanggar norma, namun bagi anak diartikan 


\section{Mengatasi Kenakalan Pada Siswa Melalui Pendekatan ...}

sebagai sesuatu yang baik dan dibenarkan oleh teman-temannya sehingga selalu dilakukan.

Dalam pengertian umum kata nakal selalu berkonotasi negatif atau anak yang melakukan perbuatan yang melanggar atau menyimpang dari biasanya maka dikatakan nakal. Lepas dari konsep nakal yang diartikan sebagai anak yang ada akalnya atau istilah nakal yang dikonotasikan sebagai anak yang menyimpang perilakunya. Dalam tulisan ini, akan menggunakan konsep nakal yang perilakunya menyimpang dari biasanya.

Dalam kenyataannya dapat kita pahami bersama bahwa anak nakal selalu dihubungkan dengan anak yang melakukan tindakan yang menyimpang. Di sekolah anak dikatakan nakal manakala anak melakukan perbuatan yang melanggar aturan atau tata tertib sekolah seperti keluar kelas pada saat pelajaran berlangsung dengan tanpa kepentingan tertentu, membuat gaduh saat pembelajaran berlangsung, tidak mengerjakan tugas dari guru berulang kali, berani dengan guru, dan sebagainya.

Kenakalan yang dilakukan anak di sekolah sebenarnya secara psikologis kurang tepat karena dalam konteks tertentu apa yang dilakukan oleh anak terkait dengan pelanggaran tata tertib di sekolah bisa terjadi pada anak karena alasan lain yang tidak selalu datang dari diri sendiri. Sebagai contoh jika anak membolos berulang kali bisa karena ada masalah dalam keluarga di rumah, atau mungkin bisa karena masalah lain. Menghadapi anak nakal di sekolah tidak bisa digeneralisir hitam putih karena banyak hal yang menentukan terjadinya perilaku nakal tersebut. Oleh karenanya dalam menghadapai kenakalan anak di sekolah harus dianalisis latar terjadinya perilaku menyimpang dan juga kapan perilaku nakal itu dilakukan anak.

Perilaku-perilaku yang dikatakan menyimpang di sekolah yang biasa dilakukan anak sebenarnya masih dapat dikatakan ringan dan secara teraputik masih dapat disembuhkan bila hal ini dilakukan scara serius dan berkelanjutan. Berdasarkan latar kejadian perilaku, maka dapat dikatakan bahwa perilaku katagori nakal yang dilakukan anak di sekolah lebih banyak dipengaruhi oleh kelompok siswa yang memang bermasalah. 
Dengan demikian anak nakal di sekolah lebih banyak ditentukan oleh adanya masalah-masalah yang dihadapi anak. Seperti anak sering membolos selolah setelah diadakan kunjungan rumah ditemukan bahwa anak sering membolsos karena orang tuanya tidak memperhatikan kebutuhan anaknya dan sebagainya. Jika kasus ini dikatakan anak nakal sesungguhnya tidak tepat karena penyebab bolos sekolah bukan dari pihak siswa tapi karena ada masalah dengan orang tua, maka penyelesaiannnya adalah dengan orang tua. Tetapi masalahnya akan berbeda jika perilaku bolos tersebut disebabkan karena anak tidak sampai sekolah tapi anak berangkat ke sekolah dan oleh orang tuanya dikira sekolah maka terapinya akan berbeda daripada kasus pertama.

Anak yang biasa melakukan perilaku yang menyimpang biasanya terdapat permasalahan yang berkecamuk dalam dirinya atau anak ingin memberontak dari semua yang dihadapi. Kalau kita analisis lebih dalam anak yang melakukan kenakalan selalu anak yang di dalam keluarganya juga bermasalah entah itu masalah orang tua tidak harmonis selalu bertengkar atau orang tuanya tidak perhatian pada anaknya, atau orang tua melepas tanggung jawab pada anaknya dengan sengaja membiarkan anak tanpa pendampingan dan kasih sayang, atau sebab orang tua kurang menaruh kasih sayang sehingga dia protes dengan melawan keinginan dan harapan orang tua, maka perilaku yang dilakukan anak akan cenderung melawan guru di sekolah.

Berdasarkan uraian di atas dapat dirumuskan permasalahan sebagai berikut: 1) apa yang dimaksud anak nakal?; 2) apa konseling behavioral?; 3) bagaimana mengatasi kenakalan siswa dengan teknik konseling behavioral?

\section{B. Pembahasan}

\section{Perilaku Anak Nakal}

Anak nakal merupakan cermin dari perilaku menyimpang dari adat dan kebiasaan yang berlaku. Anak nakal adalah anak yang mempunyai perilaku menyimpang dari adat dan kebiasaan, bahkan tatanan moral yang berlaku (Suyadi, 2009:305). Secara umum kenakalan anak diartikan sebagai tingkah laku anak yang menimbulkan persoalan bagi orang lain (Singgih Gunarso, 1990:15). 


\section{Mengatasi Kenakalan Pada Siswa Melalui Pendekatan ...}

Lebih lanjut dijelaskan bahwa kenakalan adalah tingkah laku, perbuatan anak yang merugikan dirinya sendiri atau orang lain, dan melanggar nilai-nilai moral maupun nilai-nilai sosial.

Perilaku anak dikategorikan nakal manakala perbuatan itu secara substansial melanggar norma atau aturan yang berlaku dalam masyarakat baik norma sosial, hukum, agama, maupun adab tata susila. Anak disebut nakal bila melakukan salah satu dari pelanggaran norma di atas baik sebagian atau keseluruhan, baik merugikan diri sendiri maupun orang lain.

Kendati ada konsensus di kalangan guru mengenai sebagaian bentuk kenakalan (misalnya, menolak mengerjakan tugas, memukul murid lain). Kenakalan murid bisa berkisar dari ketidak patuhan biasa (misalnya, tidak memperhatikan) sampai ke tindakan menganggu secara terbuka (misalnya, melontarkan benda diruang kelas) (Chris Kyriacou, 2011: 266).

Dari uraian di atas dapat disimpulkan bahwa anak nakal adalah anak yang dalam proses tumbuh dan kembangnya melakukan suatu perilaku yang melanggar aturan atau norma baik norma hukum, norma sosial, norma agama, dan adat istiadat atau tata kesusilaan yang dilakukan pada anak di sekolah.

Dalam tulisan ini, anak nakal adalah anak yang melakukan perbuatan melanggar norma, baik norma sosial, agama, hukum maupun adat tata susila yang dilakukan oleh siswa dalam proses pendidikan di sekolah. Kenakalan yang dilakukan anak sebenarnya banyak varian dan penyebabnya, baik yang timbul dari diri sendiri atau karena pengaruh teman sebayanya. Lepas dari persoalan dari mana terjadinya, yang dibahas dalam kajian ini adalah setelah anak melakukan tindak melanggar aturan. Singgih Gunarso (1990:23) menjelaskan bentuk-bentuk kenakalan anak adalah berbohong, pergi tanpa ijin atau kabur, mencuri, dan emosionalitas yang bermasalah.

Dinamika psikologis secara tidak langsung juga berdampak pada timbulnya perilaku-perilaku yang menyimpang dilingkungn madrasah seperti munculnya kecenderungan melanggar tata tertib sekolah. Timbulnya perilaku melanggar yang dilakukan pada anak banyak disebabkan oleh adanya interaksi atau hubungan antara anak dengan individu yang saling mempengaruhi. Pada masa anak tumbuh remaja, maka interaksi anak akan bertambah luas dan banyak, anak 
akan mulai suka di luar rumah dan suka berkelompok dengan teman sebayanya.

Dari seringnya berkelompok ini, selanjutnya anak akan banyak berperilaku karena pengaruh teman sebaya katimbang mengikuti aturan yang ditanamkan orang tua atau gurunya. Anak jadi lebih suka berperilaku yang melanggar dan menyimpang dari tatanan yang ditanamkan orang tua atau gurunya di sekolah dan lebih mengikuti atau mendapat respon yang menyenagkan dari temannya.

Dari sinilah munculnya kecenderungan anak melakukan pelanggaran yang berujung pada melanggar aturan dan normanorma sekolah, anak lebih biasa melakukan tindak melanggar dan susah diatur oleh guru. Dengan demikian, dapat disimpulkan bahwa kenakalan anak di sekolah lebih banyak disebabkan oleh adanya pengaruh dari luar terutama karena interaksi dengan teman sebayanya. Pengaruh teman sebaya bagi remaja akan berpotensi besar untuk dilakukan karena anak ingin menunjukkan dirinya berbeda dengan perilaku sebelumnya ketika masih anak. Dan anak merasa bangga karena dirinya dianggap anak "baru gede" atau "ABG", anak tidak mau diatur-atur karena menganggap dia sudah besar. Pada saat inilah orang tua dan guru lebih banyak kurang ditaati dan diikuti. Pada kondisi ini, orang tua harus memberikan perlakuan yang berbeda, sehingga anak tidak merasa diperlakukan seperti anak kecil, yang harus nuruti kata orang tua, harus ini, itu dan sebagainya. Namun orang tua harus lebih banyak mendengarkan dan memberikan pertimbangan tentang perilaku anak. Ketidak pemahaman orang tua dalam memperlakukan anaknya pada masa ini akan berakibat anak menjadi memberontak, melanggar aturan, dan tidak sedikit anak pada kondisi ini selalu melawan orang tua atau guru.

\section{Konseling Behavioral}

\section{a. Pengertian Konseling Behavioral}

Menurut aliran behavioral bahwa tingkah laku sepenuhnya ditentukan oleh aturan-aturan, bisa diramalkan, dan bisa dikendalikan. Untuk memahami tingkah laku diperlukan pendekatan yang obyektif, mekanistik, dan materialistik sehingga perubahan perilaku dapat dikondisikan (Muh.Farozin \&Kartika, 2004:72). 


\section{Mengatasi Kenakalan Pada Siswa Melalui Pendekatan ...}

Pendekatan behavioral ini digunakan untuk melakukan kegiatan psikoterapi yang bersumber pada aliran behaviorisme, yaitu suatu aliran yang menitikberatkan peranan lingkungan, peranan dunia luar sebagai faktor penting dimana seseorang dipengaruhi, seseorang belajar (Singgih Gunarso, 2009:191).

Konseling behavioral adalah konseling yang didasarkan pada upaya perubahan perilaku. Perilaku dalam pandangan ini dibentuk berdasarkan hasil dari segenap pengalamannya berupa interaksi individu dengan lingkungan sekitar (Latifun, 2001: 106). Dengan demikian perilaku manusia terbentuk dari stimulus yang diterimanya dari lingkungan.

Berdasarkan uraian di atas dapat disimpulkan bahwa konseling behavioral adalah konseling yang didasarkan pada upaya merubah perilaku berdasarkan pada pengalaman dalam berinteraksi dengan lingkungan sekitar yang dikondisikan.

Ada beberapa asumsi dalam konseling behavioral yaitu; 1) manusia baik dan buruk sebagai hasil dari pengalaman; 2) manusia mampu mengkonsepsikan dan mengendalikan perilakunya; 3) manusia mampu mendapatkan perilaku baru; 4) manusia dapat mempengaruhi perilaku orang lain dan juga dipengaruhi orang lain (Latifun, 2001:111).

Berdasarkan asumsi di atas, maka dapat dipahami bahwa manusia itu dalam hidupnya selalu belajar dari orang lain dan juga dapat membentuk perilaku orang lain. Dalam terebentuknya perilaku dikarenakan adanya stimulus dari lingkungan yang membentuknya.

\section{b. Hakekat Konseling Behavioral}

Dalam pandangan behavioral bahwa kepribadian manusia itu adalah perilaku, sedang perilaku dibentuk dari interaksi antara individu dengan lingkungannya. Dalam interaksi dengan lingkungan sesungguhnya terdapat hubungan stimulus dan respon dengan lingkungan. Dengan kata lain, pengalaman hidup setiap individu menjadi dasar dalam terbentuknya perilaku manusia.

Karena kenyataan inilah bahwa konseling behavioral pada hakekatnya adalah membentuk perilaku individu melalui modivikasi sesuai dengan perilaku yang diharapkan. Pembentukan perilaku dapat dilakukan melaui belajar dengan lingkungannya, belajar dengan dikondisikan atau dibiasakan, dan belajar operan. 
Dengan demikian dapat dikatakan bahwa hakekat konseling behavioral adalah upaya untuk membentuk perilaku melalui pembentukan kebiasaan yang berulang-ulang melalui stimulus yang dikondisikan sehingga perilaku tersebut dapat terbentuk dalam waktu yang ditentukan.

\section{c. Tujuan Konseling Behavioral}

Secara khusus tujuan konseling behavioral adalah 1).memperkuat perilaku yang adaptif; 2) memperlemah atau menghilangkan perilaku yang maladaptive; 3) mengurangi reaksi kecemasan, 4) memperkuat kapasitas relaksasi; 5) bersikap asertif; 6) berhubungan sosial secara efektif; dan 7) memperkuat kapasitas pengendalian diri (self control) (Syamsu Yusuf dan Juntika Nurihsan, 2013:137).

Tujuan konseling dalam terapi behavioral sebagaimana disampaikan Hartono \& Boy Soedarmadji (2012:124) adalah untuk mengubah dan menghapus perilaku yang buruk dengan menggunakan cara belajar yang baru yang lebih dikehendaki.

Secara umum, tujuan dari terapi behavioral adalah menciptakan suatu kondisi baru yang lebih baik melalui proses belajar sehingga perilaku simtomatik dapat dihilangkan. Sementara itu tujuan terapi behavioral secara khusus adalah mengubah tingkah laku adaptif dengan cara memperkuat tingkah laku yang diharapkan dan meniadakan perilaku yang tidak diharapkan serta berusaha menemukan cara-cara bertingkah laku yang tepat (Namora Lumongga Lubis, 2011:171).

Berdasarkan beberapa pendapat di atas dapat disimpulkan bahwa tujuan konseling behavioral adalah sebagai berikut: 1) untuk mengubah dan menghapus perilaku yang buruk dengan menggunakan cara belajar yang baru yang lebih sesuai dan dikehendaki; 2) memperkuat perilaku yang adaptif, dan memperlemah atau menghilangkan perilaku yang maladaptive; 3) membentuk sikap asertif.

Konseling behavioral sebenarnya merupakan konseling untuk merubah perilaku klien menjadi lebih baik melalui penguatan perilaku yang baik dan melemahkan atau merubah perilaku yang tidak baik. 


\section{Mengatasi Kenakalan Pada Siswa Melalui Pendekatan ...}

\section{d. Langkah-Langkah Konseling Behavioral}

Dalam konseling behavioral ada beberapa langkah yang bisa dilakukan, yaitu menurut Gibson dan Mitchell (Latifun, 2001: 115) sebagai berikut:

1) Belajar operan yaitu, belajar didasarkan atas perlunya pemberian ganjaran untuk menghasilkan perubahan perilaku yang diharapkan, ganjaran dapat diberikan dalam bentuk dorongan dan penerimaan sebagai persetujuan, pembenaran, atau perhatian konselor terhadap perilaku yang dilakuakn klein;

2) Belajar mencontoh yaitu belajar cara dalam memberikan respon baru melalui menunjukkan atau mengerjakan model-model perilaku yang diinginkan sehingga dapat dilakuakn oleh klien;

3) Belajar kognitif yaitu, belajar memelihara respon yang diharapkan dan boleh mengadaptasi perilaku yang lebih baik melalui intruksi sederhana;

4) Belajar emosi yaitu cara yang digunakan untuk mengganti respon-respon emosional klien yang tidak dapat diterima menjadi respon emosional yang dapat diterima sesuai dengan konteks classical conditionaing.

Langkah-langkah konseling behavioral meliputi 1) Assesment, 2) goal setting, 3) Technique implementation, 4) Evaluation termination, dan 5) feedback. Pertama, yang dilakukan adalah memberikan kesempatan pada klien untuk mau menyampaikan apa yang dialaminya dengan sejujur-jujurnya tentang kegagalan, kelebihan, kekurangan, dan kehidupan kejiwaan yang dihadapi secara terbuka tanpa ada yang ditutup-tutupi. Konselor memberikan penguatan pada klien tentang data yang diberikan dan berjanji untuk merahasiakan semua data klien. Informasi yang disampaikan klien akan berguna dalam menentukan teknik mana yang akan ditempuh untuk merubah perilaku pada klien.

Kedua, goal setting yaitu merumuskan masalah dalam konseling, pada langkah asessmen sudah ditentukan tujuannya yang ingin dicapai. Perumusan tujuan konseling dilakukan dengan tahapan sebagai berikut : (a) Konselor dan klien mendifinisikan masalah yang dihadapi klien; (b) Klien mengkhususkan perubahan positif yang dikehendaki sebagai hasil konseling; (c) Konselor dan klien 
mendiskusikan tujuan yang telah ditetapkan klien : (a) apakah merupakan tujuan yang benar-benar dimiliki dan diinginkan klien; (b) apakah tujuan itu realistik; (c) kemungkinan manfaatnya; dan (d) kemungkinan kerugiannya; (e) Konselor dan klien membuat keputusan apakahmelanjutkan konseling dengan menetapkan teknik yang akan dilaksanakan, mempertimbangkan kembali tujuan yang akan dicapai, atau melakukan referal. Ketiga, technique implementation, yaitu menentukan teknik yang akan dilakukan dalam pelaksanaan konseling behavioral dalam rangka mencapai perubahan perilaku yang dikehendaki dalam konseling. Keempat, evaluation termination yaitu, menilai kegiatan yang dilakukan apakah sudah berahasil atau tidak pelaksanaan konseling yang dilakukan. Kelima, Feedback, yaitu menganalisis kekurangan yang dialami dalam konseling dan memperbaiki dalam rangka mencapai hasil yang lebih maksimal (Akhmad Sudrajat, 2008).

Konseling behavioral merupakan suatu proses membantu orang untuk memecahkan masalah. Interpersonal, emosional dan keputusan tertentu. Urutan pemilihan dan penetapan tujuan dalam konseling yang digambarkan oleh cornier dan Cornier sebagai salah satu bentuk kerja sama antara konselor dan klien sebagai berikut: 1). Konselor menjelaskan maksud dan tujuan, 2) Klien mengkhususkan perubahan positif yang dikehenadaki sebagai hasil konseling, 3) Klien dan konselor menetapkan tujuan yang telah ditetapkan apakah merupakan perubahan yang dimiliki oleh klien, 4) Bersama-sama menjajaki apakah tujuan itu realistik, 5) Mendiskusikan kemungkinan manfaat tujuan, 6) Mendiskusikan kemungkinan kerugian tujuan, 7) Atas dasar informasi yang diperoleh tentang klien, konselor dan klien membuat salah satu keputusan berikut: untuk meneruskan konseling atau mempertimbangkan kembali tujuan akan mencari referral (Deni Febrini, 2011:54-56).

Berdasarkan uraian di atas dapat disimpulkan bahwa langkah-langkah konseling behavioral adalah sebagai berikut: 1) konseling behavior dimulai dengan mengadakan perubahan perilaku pada klien melalui pemberian penguatan atau ganjaran secara berulang-ulang agar perilaku yang kondisikan dapat menetap; 2) setelah perilaku yang diinginkan tetap dilakukan atau setelah terjadinya perilaku baru yang sesuai, maka klien harus diberikan 


\section{Mengatasi Kenakalan Pada Siswa Melalui Pendekatan ...}

interuksi yang harus dilakukan secara terus-menerus; 3) selanjutnya perilaku tersebut harus dikondisikan agar tetap ada dengan berbagai pengalaman-pengalaman yang dialami; 4) berikutnya merubah emosi yang dialami menjadi emosi yang dapat diterimanya.

\section{e. Teknik Konseling Behavioral}

Didalam kegiatan konseling behavioral, tidak ada suatu teknik konselingpun yang selalu harus digunakan, Teknik konseling itu harus disesuaikan dengan kebutuhan individual klien dan tidak ada suatu teknikpun digunakan melulu untuk semua kasus (Sofyan S. Willis, 2013:71).

Teknik behavioral dibagi dalam dua bagian, yaitu teknikteknik tingkah laku umum dan teknik-teknik spesifik. Pertama, Teknik -teknik tingkah laku umum, teknik ini terdiri dari beberapa bentuk, diantaranya adalah : a) Shaping adalah teknik terapi yang dilakukan dengan mempelajari tingkah laku baru secara bertahap. Konselor dapat membagi-bagi tingkah laku yanh ingin dicapai dalam beberapa unit, kemudian mempelajarinya dalam unit-unit kecil, b) Ekstingsi adalah teknik terapi berupa penghapusan penguatan agar tingkah laku maladaptive tidak berulang. Ini didasarkan pada pandangan bahwa individu tidak akan bersedia melakukan sesuatu apabila tidak mendapatkan keuntungan (Namora Lumangga Lubis, 2013:172).

Kedua, Teknik-teknik Spesifik, teknik-teknik spesifik ini meliputi: a) Desensitiasi sistematik adalah teknik yang paling sering digunakan. Teknik ini diarahkan kepada klien untuk menampilkan respons yang tidak konsisten dengan kecemasan. Desensitisasi sistematik melibatkan teknik relaksasi dimana klien diminta untuk menggambarkan situasi yang paling menimbulkan kecemasan sampai titik dimana klien tidak merasa cemas, b) Pelatihan asertivitas. Teknik ini mengajarkan klien untuk membedakan tingkah laku agresif, pasif, dan asertif. Prosedur yang digunakan adalah permainan peran. Teknik ini dapat membantu klien yang mengalami kesulitan untuk menyatakan atau menegaskan diri dihadapan orang lain, c) Time-Out. Merupakan teknik aversif yang sangat ringan. Apabila tingkah laku yang tidak diharapkan muncul, maka klien akan dipisahkan dari penguatan positif. Time-Out akan lebih efektif bila 


\section{dilakukan dalam waktu yang relative singkat (Namora Lumangga} Lubis, 2013:173).

\section{Prosedur dan tahapan konseling behavioral dapat dilihat} dalam konstalasi berikut:

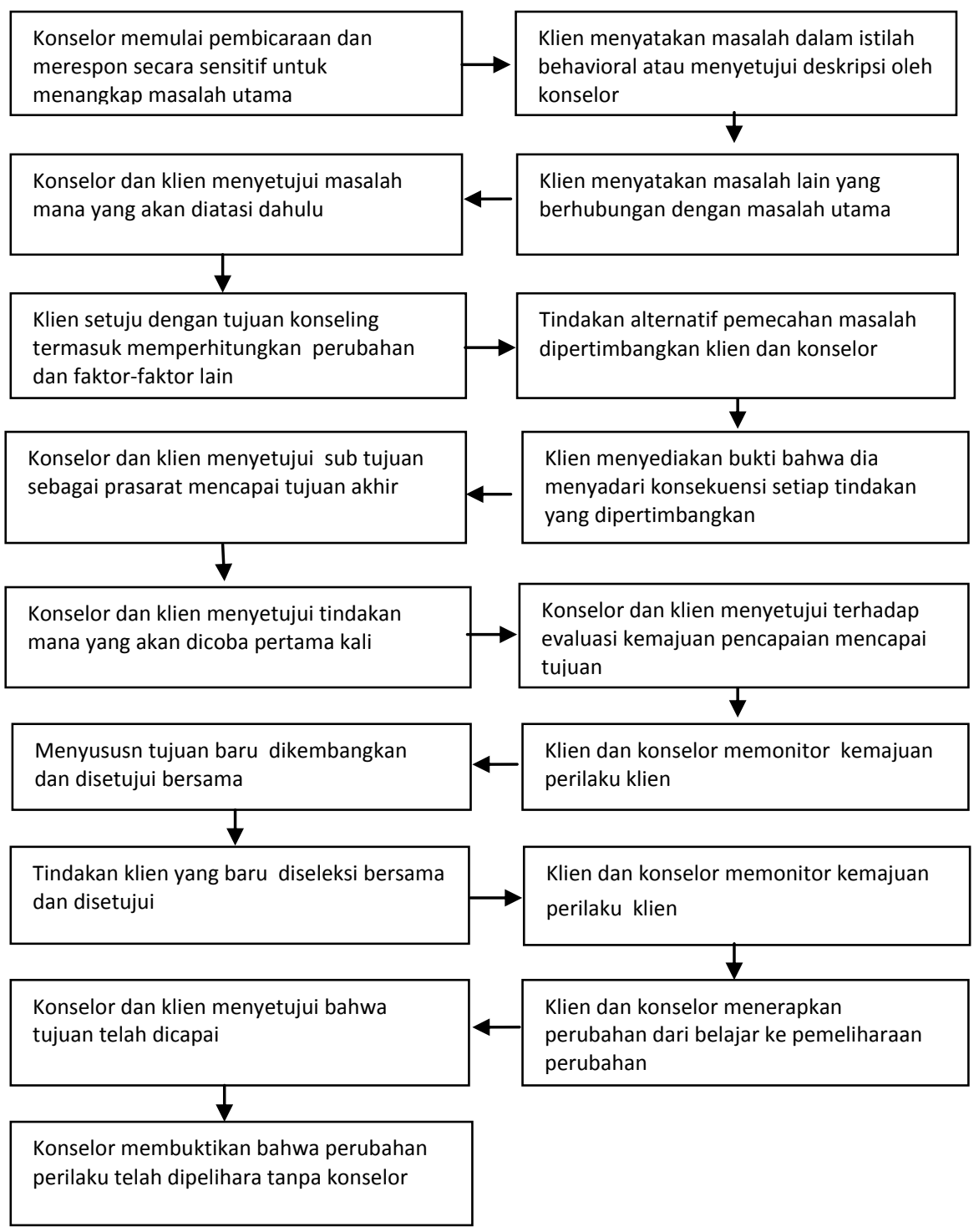




\section{Mengatasi Kenakalan Pada Siswa Melalui Pendekatan ...}

Bagan 1. Prosedur dan tahapan konseling behavioral (Latifun,

$$
\text { 2001:117) }
$$

Teknik-teknik spesifik sebagaimana diungkapkan oleh Goldenberg 1983 (Latifun, 2001:118-120) adalah sebagai berikut: 1) desensitisasi sistemik, 2) terapi implosif, 3) latihan perilaku asertif, 4) pengkondisian aversi, 5) pembentukan perilaku model, dan kontrak perilaku. Kedua teknik di atas sebenarnya merupakan bagian yang tak terpisahkan dalam melaksanakan konseling behavioral. Dalam usaha untuk merubah perilaku bermasalah agar kembali menjadi individu yang berperilaku adaptif. Sebelum memulai memberikan layanan konseling behavioral, maka terlebih dahulu harus diawali dengan mempelajari perilaku yang akan dirubah pada klien akan dipelajari dan diamati teknik-teknik mulai dari persiapan hingga samapi yang paling tinggi.

Selanjutnya merubah perilaku-perilaku yang adaptif. Setelah itu dimulailah teknik konseling dengan memberikan respon yang tidak sesuai dengan kecemasan, klien diberikan latihan desensitisasi dengan relaksasi untuk mengurangi kecemasan. Selanjutnya diadakan pelatihan asertivitas melalui permainan peran dan penguatan positif.

Masalah-masalah yang kita hadapi harus segera kita atasi agar tidak menimbulkan adanya konflik dan tekanan yang berkepanjangan, oleh karenanya dibutuhkan adanya upaya penyelesaian masalah tadi melalui bimbingan dan konseling. Dalam banyak kasus orang yang terkena masalah biasanya susah mencari penyelesaian sendiri dan cenderung masalah tersebut berdampak pada terjadinya tekanan yang sangat mengganngu jika tidak segera diatasi, dan tidak heran jika berlanjut pada timbulnya gangguan jiwa dan berpikir tidak realistis. Oleh karena itu maka dibutuhkan adanya bimbingan dan konseling.

Hampir semua masalah yang timbul secara historis bermula dari adanya berpikir yang kurang realistik sehingga menerima sesuatu dalam hidup yang dialami dari kehidupan emosinya. Dalam menghadapi hidup yang emosional tersebut akan berpengaruh pada kurangnya kesadaran dan penerimaan diri sehingga seseorang selalu merasa kurang tenang, kurang nyaman, iri, dengki, dan hasut yang berimbas pada perilaku yang negatif. Hal ini jika tidak segera dilepas 
maka akan timbul adanya konflik yang menyebabkan seseorang menjadi tidak tercapai ketenangan jiwa dan akan selalu dipikirkan sehingga membelenggu hati dan pikirannya

Hal yang perlu dilakukan adalah merubah pikiran individu bermasalah dengan selalu berpikir positif dan berperilaku secara wajar. Semua tekanan yang dirasakan konseli lebih disebabkan karen adanya pola pikir yang salah sehingga berdampak pada timbulnya perilaku yang kurang realistis dan cenderung merasa menyalahkan orang lain. Setelah pikiran dan perasaannya sudah baik maka perilakunya juga akan membaik. Oleh karenanya dalam konteks ini yang perlu dilakukan adalah merubah perilaku konseli.

Dalam merubah perilaku dalam konseling dimulai dari 1) ajakan terbuka untuk berbicara; 2) pertanyaan terbuka; 3) mengikuti pokok pembicaraan; 4) dorongan minimal; 5) mendengar secara tepat dan aktif; 6) ajakan untuk mengikirkan sesuatu yang lain; 7) kesegaran; 8) suasana diam (Munro, dkk.,1985: 48-54).

Agar konseli mau menuturkan permasalahan yang dihadapi, maka seorang konselor harus bersikap hangat, bersahabat, dan antusiasme untuk menerima kedatangan konseli dengan muka yang ramah, harmonis dan empati. Selanjutnya konseli diberikan kesempatan untuk mau berbicara secara bebas, terbuka dan konselor siap membantu dan mendengarkan dengan seksama. Jika konseli belum bisa berbicara maka tugas konselor adalah mengajak konseli mau menuturkan masalah yang dihadapi secara terbuka sehingga dapa diprediksikan masalah yang dihadapi dan kemudian dicarikan langkah-langkah solusi.

Dalam langkah kedua ini konseli diharapkan dapat mengemukakan pertanyaan terbuka agar konseli mau meneruskan pembicaraannya dan membeberkan masalahnya sehingga konseli akan merasa lega karena beban yang dialaminya sudah di curahkan kepada orang lain.

Langkah ketiga, konselor harus memusatkan perhatian pada apa yang disampaikan konseli, konselor harus betul-betul antusias menerima dan memperhatikan permasalahan yang dituturkan konseli sehingga konseli akan merasa termotivasi untuk bercerita lebih banyak dan hingga tuntas, hal ini membantu konselor dalam memberikan treatment masalah. 


\section{Mengatasi Kenakalan Pada Siswa Melalui Pendekatan ...}

Langkah keempat, konselor memberikan dorongan pada konseli agar tetap menyampaikan apa yang dirasakan secara tuntas, kemudian konselor setia mendengarkan apa yang disampaikan oleh konseli dengan menunjukkan keseriusan dan keantusiasan dalam mendengarkan sehingga konseli tetap bersemangat untuk berbicara, dan jika konseli merasa melemah atau tidak bersemangat lagi dalam menyampaikan keluhannya maka konselor harus tetap mendorongnya dengan memotivasi terus.

Langkah kelima, konselor mengajak konseli untuk memikirkan sesuatu yang lain. Setelah konseli memaparkan permasalahan yang dihadapi secara panjang lebar dan dianggap cukup, maka konselor mengajak konseli untuk berpikir alternatif yang lain yang masih ada hubungannya dengan apa yang sekarang dipikirkan.

Hal-hal yang dapat dilakukan dalam rangka merubah tingkah laku konseli adalah sebagai berikut. 1). Merumuskan tujuan; 2) Meneguhkan hasrat untuk melakukan sesuatu; 3) Menghadapi apa yang akan terjadi; 4) Menilai hasil; 5) Membuat catatan (Munro, dkk.,1985: 86-110).

Merumuskan tujuan, terkadang banyak diantara konseli yang kurang jelas tujuan yang ingin dicapai dan kalaupun mampu menyampaikan tujuan yang diinginkan namun tidak jelas. Dalam hal ini konselor bertugas untuk memperjelas dan mengarahkan konseli pada tujuan yang lebih khusus atau spesifik. Dengan tujuan yang jelas ini maka konseli akan dapat merubah dalam bentuk perilaku untuk mencapai tujuan yang ingin dicapainya.

Meneguhkan hasrat untuk melakukan sesuatu, setelah konseli menentukan tujuan yang ingin dicapai, maka konselor lebih menguatkan tujuan yang ingin dicapai tersebut. Jika tujuan yang ingin dicapai oleh konseli benar-benar disadari dan diinginkan maka kekuatan untuk mencapainya dengan usaha yang keras akan terlaksana. Kerja keras dalam merubah perilaku dalam rangka mencapai tujuan yang diinginkan adalah sebuah kekuatan besar yang dimiliki oleh konseli untuk mencapai tujuan yang diinginkan.

Menghadapi apa yang akan terjadi, setelah konseli memiliki tujuan yang kuat dan kokoh, maka konselor bertugas untuk mengawal rencana-rencana apa yang harus dilaksanakan dan 
perilaku apa yang dirubah dalam rangka merencanakan pencapaian tujuan. Kapan, bagaimana, dan dimana proses pengubahan tingkah laku akan dimulai. Konseli disadarkan bahwa banyak faktor yang ikut mempengaruhi dalam mencapai keberhasilan usahanya. Oleh karenanya maka konseli disadarkan tentang kenyataan-kenyataan yang akan terjadi terkait dengan tujuan yang ingin dicapai, dalam kenyataan manakala tujuan yang ingin dicapai belum berhasil maka disarankan untuk memiliki jiwa lapang dan berusaha lebih sungguhsungguh dengan belajar dari penyebab kegagalan tersebut.

Menilai hasil, setelah menjalankan rencana dalam perubahan tingkah laku dalam mencapai hasil yang diinginkan maka konselor harus membicarakan pengalaman-pengalaman yang telah dilakukan dan menguatkan agar konseli mau menjalankan kembali usaha-usah tersebut hingga berhasil. Dalam membicarakan faktor-faktor yang mempengaruhi keberhasilan maka konselor wajib membangkitkan semangat agar belajar dari pengalaman dan bertahan untuk mau mengulangi usaha tersebut.

Membuat catatan, peristiwa yang dilalui baik berupa kegiatan atau peristiwa-peristiwa yang terjadi selama perubahan tingkah laku, maka dibutuhkan adanya perekaman atau pendokumenan semua kegiatan agar dapat dilacak kembali saat dibutuhkan untuk mempelajari kegagalan dalam pencapaian tujuan. Catatan selama perubahan tingkah laku baik diri sendiri maupun tingkah laku orang lain dapat direnungkan dan dievaluasi tentang apa-apa yang menyebabkan perilaku tersebut berpengaruh dalam pencapaian tujuan yang diinginkan.

Hal yang juga berpengaruh dalam perubahan tingkah laku konseli adalah menyangkut berbagai teknik dalam konseling, diantaranya bagaimana konselor memberikan ganjaran atau reward sehingga membangkitkan gairah untuk melakukan perubahan tingkah laku dalam mencapai tujuan. Sedang yang tak kalah pentingnya dalam proses pengubahan tingkah laku adalah memberikan contoh-contoh nyata kepada konseli agar mereka lebih mengerti dan mampu menyerap apa yang harus dilakukan.

Demikian proses perubahan tingkah laku yang dilakuka konseli melalui proses konseling, semua itu akan berjalan secara dinamis bergantung pada jenis permasalahan konseli, berat 


\section{Mengatasi Kenakalan Pada Siswa Melalui Pendekatan ...}

ringannya masalah, cepat lambatnya penerimaan dan kesadaran konseli serta kuat lemahnya keinginan konseli dalam merubah tingkah lakunya dalam rangka menjacapai tujuan yang diinginkan.

\section{Penerapan Konseling Behavioral dalam Mengatasi Masalah Kenakalan Siswa.}

Konseling behavioral itu memiliki ciri; 1) Berfokus pada perilaku yang tampak dan spesifik, 2) memerlukan kecermatan dalam perumusan tujuan teraputik, 3) mengembangkan prosedur perlakuan spesifik sesuai dengan masalah klien, 4) penaksiran obyektif atas tujuan teraputik (Corey, 1977) dalam Latifun (2001: 113).

Perilaku bermasalah dalam pandangan behavioral dapat dimaknakan sebagai perilaku atau kebiasaan-kebiasaan negative atau perilaku yang tidak tepat, yaitu perilaku yang tidak sesuai dengan yang diharapkan. Perilaku yang salah penyesuaian terbentuk melalui proses interaksi dengan lingkungannya. Artinya bahwa perilaku individu itu meskipun secara sosial adalah tidak tepat, dalam beberapa saat memperoleh gajaran dari pihak tertentu.

Perilaku yang salah dalam penyesuaian berbeda dengan perilaku normal. Perbedaan ini tidak terletak pada cara mempelajarinya, tetapi pada tingkatannya, yaitu tidak wajar dipandang. Dengan kata lain, perilaku dikatakan mengalami salah penyesuaian jika tidak selamanya membawa kepuasan bagi individu atau pada akhirnya membawa individu konflik dengan lingkunganya. Kepuasan individu terhadap perilakunya bukanlah ukuran bahwa perilaku itu harus dipertahankan, karena adakalanya perilaku itu dapat menimbulkan kesulitan dikemudian hari. Perilaku yang perlu diperatahankan atau dibentuk pada individu adalah perilaku yang bukan sekedar memperoleh kepuasaan pada jangka pendek, tetapi perilaku yang menghadapi kesulitan-kesulitan yang lebih luas, dan dalam jangka yang lebih panjang (Sulistyarini dan Muh. Jauhar, 2014:1120).

Untuk menangani perilaku bermasalah, dapat dilakukan dengan mengidentifikasi masalah yang dilakuakn anak tersebut, oleh karena itu kita harus lebih terbuka terhadap masalah yang dialami anak, apakah anak memiliki permasalahan apa sehingga anak melakukan perilaku yang salah atau menyimpang. Ajaklah anak 
untuk mau berbicara dan menyampaikan apa yang menjadi persoalan kenapa dia melakukan. Jawaban apapun dari anak tetap ditampung dan jika jawaban anak belum sesuai atau anak tidak mau menjelaskan kejadian sebenarnya maka kita harus memotivasi dan memancing-mancing pembicaraan agar dia mau berkata sejujurnya. Dari perkataan anak itulah nanti kita akan memberikan solusi yang ideal sesuai dengan masalah yang dihadapi anak.

Untuk menghadapi anak tersebut maka perlu diciptakan suasana yang lebih demokratis, menghargai anak dan memperlakukan anak seperti layaknya untuk tidak merasa takut atau tertekan tapi sebaliknya jadikan anak mau bercerita dan mengurai apa yang dihadapi sambil memotivasi dan sedikit-demi sedikit membangkitkan rasa untuk kembali menjadi baik lagi.

Apapun kondisi anak itulah yang harus dihadapi dan diperlakukan sebagai sasaran untuk dibina agar menjadi lebih baik. Anak adalah manusia yang belum jadi, dan dalam proses menjadi sehingga dibutuhkan arahan dan nasihat manakala terjadi permasalah, masalah yang harus diselesaikan harus berbasis pada perilaku yang dilakukan anak baik menyangkut kenapa dan apa yang telah dilakukan serta kenapa dilakukan, setelah ditemukan baru diadakan lakukan kuratif. Semua masalah kenakalan anak di sekolah jika dianalisis penyebabnya dapat dikelompokkan menjadi 2 (dua) penyebab utama yaitu pertama, masalah internal, yaitu masalah yang timbul dalam diri pribadi, kenakalan anak yang timbul dari dalam diri anak biasanya berasal dari sifat atau kepribadian anak. Anak memiliki sifat pribadi yang lain dari biasanya timbul karena pembiasaan dalam kehidupan keluarga seperti anak dibiasakan pergi dan pulang kemana-mana tidak pamit, atau dibiarkan mengambil uang di dompet orang tuanya tanpa ijin atau kebiasaan lain yang tidak benar, dan kedua, penyebab eksternal, yaitu masalah yang disebabkan karena pengaruh dari luar seperti teman sebaya, lingkungan sekitar atau komunitas teman sebaya dalam bentu "geng".

Ketika anak mengalami permasalahan dalam keluarga karena tidak terdapat keharmonisan dan kenyamanan di rumah, maka anak akan lebih suka tinggal di luar rumah atau bersama teman-temannya. 


\section{Mengatasi Kenakalan Pada Siswa Melalui Pendekatan ...}

Dari sinilah munculnya perilaku kenakalan yang disebabkan pengaruh dari luar.

Anak yang menginjak remaja lebih banyak menghadapi dinamika psikologis yang terkadang melakukan perilaku yang menyimpang atau bertentangan dengan aturan atau norma yang terjadi dalam masyarakat. Secara presedural terjadinya perubahan pada remaja secara psikososial dibagi dalam tiga tahap yaitu remaja awal (early adolescent), pertengahan (middle adolescent), dan akhir (late adolescent). Periode pertama disebut remaja awal atau early adolescent, terjadi pada usia usia 12-14 tahun. Pada masa remaja awal anak-anak terpapar pada perubahan tubuh yang cepat, adanya akselerasi pertumbuhan, dan perubahan komposisi tubuh disertai awal pertumbuhan seks sekunder. Karakteristik periode remaja awal ditandai oleh terjadinya perubahan-perubahan, yaitu antara lain; 1) Krisis identitas, 2) jiwa yang labil, 3) meningkatnya kemampuan verbal untuk ekspresi diri, 4) pentingnya teman dekat/sahabat, 5) berkurangnya rasa hormat terhadap orangtua, kadang-kadang berlaku kasar menunjukkan kesalahan orangtua (Santrock, 2003:84).

\section{Simpulan}

Anak nakal adalah anak yang dalam proses tumbuh dan kembangnya melakukan suatu perilaku yang melanggar aturan atau norma baik norma hukum, norma sosial, norma agama, dan adat istiadat atau tata kesusilaan yang dilakukan pada anak di sekolah.

Konseling behavioral adalah konseling yang didasarkan pada upaya merubah perilaku berdasarkan pada pengalaman dalam berinteraksi dengan lingkungan sekitar yang dikondisikan. Langkahlangkah konseling behavioral adalah sebagai berikut: 1) konseling behavior dimulai dengan mengadakan perubahan perilaku pada klien melalui pemberian penguatan atau ganjaran secara berulang-ulang agar perilaku yang kondisikan dapat menetap; 2) setelah perilaku yang diinginkan tetap dilakukan atau setelah terjadinya perilaku baru yang sesuai, maka klien harus diberikan interuksi yang harus dilakukan secara terus-menerus; 3) selanjutnya perilaku tersebut harus dikondisikan agar tetap ada dengan berbagai pengalaman- 
Sulthon

pengalaman yang dialami; 4) berikutnya merubah emosi yang dialami menjadi emosi yang dapat diterimanya. 


\section{Mengatasi Kenakalan Pada Siswa Melalui Pendekatan ...}

\section{DAFTAR PUSTAKA}

Chris Kyriacou, 2011. Effective Teaching Theory and Practice, Bandung: Nusamedia, ubara. 2010. Adolescent development (Perkembangan Remaja, Jakarta: Departemen Ilmu Kesehatan Anak, RS Dr. Cipto Mangunkusumo, Fakultas Kedokteran Universitas Indonesia, Jakarta, Sari Pediatri, Vol. 12, No. 1, Juni 2010.

Deni Febrini, 2011. Bimbingan Konseling, Yogyakaarta: Teras.

Hartono \& Boy Soedarmadji, 2012. Psikologi Konseling, Jakarta: Kencana.

https://akhmadsudrajat.wordpress.com/2008/01/23/pendekatan-

konseling-behavioral/diakses,09-10-2017

Latipun. 2001. Psikologi Konseling, Malang: UMM Press.

Moh. Farozin dan Kartika Nur Fathiyah. 2004. Pemahaman Tingkah Laku. Jakarta: Rineka Cipta.

Munro, E.A., Manthei, R.J., Small, J.J. 1985. Penyuluhan (Konseling) Suatu Pendekatan Berdasarkan Keterampilan, Jakarta: Yudhistira.

Namora Lumongga Lubis, 2011. Memahami Dasar-Dasar Konseling dalam Teori dan Praktik, Jakarta: Kencana.

Singgih D Gunarsa. 2009. Konseling Dan Psikoterapi, Jakaarta: PT BK Gunung Mulia.

Singgih Gunarso. 1990. Psikologi Anak Bermasalah, Jakarta: Gunung Mulia.

Sofyan S. Willis,2013. Konseling Individual, Teori Dan Praktek, Bandung: Alfabeta.

Sulistyarini dan Mohammad Jauhar, 2014. Dasar-Dasar Konseling, Jakarta: Prestasi Pustaka.

Suyadi. 2009. Bimbingan Konseling Untuk PAUD, Yogyakaarta: Diva Press.

Syamsu Yusuf dan Juntika Nurihsan, 2012. Teori Kepribadian, Bandung: PT Remaja Rosdakarya.

Tanner J M. 1989. Foetus into Man. Edisi ke-2. Inggris: Castlemead Publication. 